\title{
Governmental surveillance system of healthcare-associated infection in Brazil*
}

\author{
SISTEMAS GOVERNAMENTAIS DE VIGILÂNCIA DE INFECÇÕES RELACIONADAS À \\ ASSISTÊNCIA À SAÚDE NO BRASIL
}

\author{
SISTEMAS GUBERNAMENTALES DE VIGILANCIA DE LAS INFECCIONES RELACIONADAS \\ CON LA ATENCIÓN A LA SALUD EN BRASIL
}

\author{
Cassimiro Nogueira Junior ${ }^{1}$, Maria Clara Padoveze ${ }^{2}$, Rúbia Aparecida Lacerda ${ }^{3}$
}

\begin{abstract}
Objective: This study aimed to describe the structure of governmental surveillance systems for Healthcare Associated Infection (HAI) in the Brazilian Southeastern and Southern States. Method: A cross-sectional, descriptive and exploratory study, with data collection by means of two-phases: characterization of the healthcare structure and of the HAl surveillance system. Results: The governmental teams for prevention and control of HAl in each State ranged from one to six members, having at least one nurse. All States implemented their own surveillance system. The information systems were classified into chain $(n=2)$, circle $(n=4)$ or wheel $(n=1)$. Conclusion: Were identified differences in the structure and information flow from governmental surveillance systems, possibly limiting a nationwide standardization. The present study points to the need for establishing minimum requirements in public policies, in order to guide the development of HAI surveillance systems.
\end{abstract}

\section{DESCRIPTORS}

Surveillance

Cross infection

Government Programs

\section{RESUMO}

Objetivo: Este estudo objetivou descrever a estrutura dos sistemas governamentais de vigilância de Infecções relacionadas à Assistência à Saúde (IRAS) nos Estados do Sudeste e Sul do Brasil. Método: Estudo transversal, descritivo e exploratório, com coleta de dados por meio de duas fases: $\mathrm{ca}$ racterização das estruturas de assistência à saúde e do sistema de vigilância de IRAS. Resultados: As equipes governamentais para a prevenção e controle de IRAS em cada Estado variou de um a seis membros, tendo pelo menos um enfermeiro. Todos os Estados implantaram um sistema de vigilância próprio. Os sistemas de informação foram classificados em cadeia $(n=2)$, círculo $(n=4)$ e roda $(n=1)$. Conclusão: Foram identificadas variações na estrutura e fluxo de informação dos sistemas governamentais de vigilância, podendo limitar sua uniformização em âmbito nacional. O presente estudo aponta a necessidade de estabelecer requisitos mínimos em políticas públicas para orientar o desenvolvimento dos sistemas de vigilância de IRAS.

\section{RESUMEN}

Objetivo: El presente estudio ha tenido como objetivo describir la estructura de los sistemas gubernamentales de vigilancia de las Infecciones Relacionadas con la Atención a la Salud (IRAS) en Sureste y Sur de Brasil. Método: Estudio transversal, descriptivo y exploratorio, con recolección de datos en dos fases: caracterización de las estructuras de asistencia a la salud y del sistema de vigilancia de las IRAS. Resultados: Los equipos gubernamentales para la prevención y el control de las IRAS en cada Estado variaron de uno a seis miembros, con al menos un enfermero. Todos los Estados implantaron su propio sistema de vigilancia. Los sistemas de información fueron clasificados en cadena $(\mathrm{n}=2)$, círculo $(n=4)$ y rueda $(n=1)$. Conclusión: Se han identificado variaciones en la estructura y el flujo de información de los sistemas gubernamentales de vigilancia que pueden limitar su uniformización en ámbito nacional. Este estudio apunta la necesidad de establecer requisitos mínimos en políticas públicas para guiar el desarrollo de los sistemas de vigilancia de las IRAS.

\section{DESCRIPTORES \\ Vigilancia \\ Infección hospitalaria \\ Programas de Gobierno}

\footnotetext{
* Extracted from the dissertation "Sistemas de informação sobre infecção relacionada à assistência à saúde (IRAS): delineando a realidade das regiões sudeste e sul do Brasil", School of Nursing, University of São Paulo, 2013. ${ }^{1}$ MS, RN, School of Nursing, University of São Paulo, São Paulo, SP, Brazil. 2 PhD Nursing, RN, Department of Collective Health Nursing, School of Nursing, University of São Paulo, SP, Brazil. ${ }^{3}$ PhD Nursing, RN, Department of Medical
} Surgical Nursing, School of Nursing, University of São Paulo, São Paulo, SP, Brazil. 


\section{INTRODUCTION}

An essential measure to prevent healthcare associated infections (HAI) is to create a consistent system of surveillance, thus promoting a reliable situation diagnosis in order to perform efficient control for the problem ${ }^{(1-2)}$.

Since the 1970s, these HAI surveillance systems have been evolving in various countries and regions of the world. The North-American and European systems stand out as pioneers of this movement and have been achieving favorable results ${ }^{(3-8)}$.

Brazil, a continent-sized country, has States with relative political autonomy, and the assumptions of organization of National Health System warrants a decentralized process. Therefore, several initiatives to pursue the conception of HAl surveillance systems are being generated in these States. Nevertheless, this is a reality still partially unknown, which can lead to the formation of disintegrated and individualized networks ${ }^{(9)}$.

Despite the process of HAI governmental surveillance systems developing worldwide there are no published studies relating their characteristics. Accordingly, to contribute to this area of knowledge, this study has as its objective the characterization of the HAl surveillance system in States in the Southeastern and Southern regions of Brazil, seeking to understand how these systems are structured and what are the characteristics of their information flow.

\section{METHOD}

\section{Design}

A cross-sectional, descriptive and exploratory study of the characterization of HAl governmental surveillance systems implemented in Brazilian States in the Southeastern and Southern regions. These regions were selected once they represent more than half of available healthcare settings in the country.

\section{Settings and population}

The Brazilian Southeastern and Southern regions have seven States - four in the Southeast and three in the South. The study was performed in the HAl control and prevention division of each State Health Department (SHD). Were invited to participate in the study each State Coordinator in charge of the HAl surveillance systems in these regions. None refused participation, which totaled seven managers that agreed through a consent form.

\section{Data collection}

The study was carried out in two phases: I) characterization of healthcare structures in each State; II) characterization of HAI surveillance system in the States.
A semi-structured instrument was used for data collection, which was previously submitted to a pilot-test for adjustments in its structure and contents. This test took place in one of the studied SHD, selected by convenience. Phase I: information was obtained through consultation of secondary data of public access in web pages of the Brazilian Institute of Geography and Statistics (IBGE,www.ibge. gov.br) and Brazilian Registry of Health Institutes (CNES, cnes.datasus.gov.br) on June 4, 2012. Phase II: data were obtained through interviews with managers of HAl prevention and control programs in the States from June to August 2012.

\section{Data analysis}

Data were analysed based on three main variables: 1) healthcare structure, which included the characterization of the absolute number and ratios of population and healthcare services (including primary, secondary and tertiary level); 2) operational structure for surveillance services of $\mathrm{HAl}$, which included the identification of their components, such as human, physical and organizational resources; 3 ) characterization of HAl surveillance systems, focused on their components, data flows, and strategies adopted for continuous improvement. The information systems were classified into three categories, according to their data flow: 1) chain (in which information flows through government levels without feedback to notifying hospitals); 2) circle (in which information flows through government levels with feedback to notifying hospitals); 3) wheel (in which information is primarily transmitted to a hub - by using software - which simultaneously flows to different government levels) $)^{(10)}$

A continuous improvement in the evaluated systems was considered as being present whenever we identified of the existence of maintenance and reviewing processes aiming at detecting and correcting errors in the data gathered; a structure for cycles of data auditing; and educational practices to maintain the full-functionality of the system.

\section{Ethical issues}

The research project was submitted to the Ethical Research Committee of the School of Nursing of the University of São Paulo, by approval protocol number 7887. One of the State SHD also required a previous project examination by its Ethical Committee, with favourable manifestation on June 19, 2012.

\section{RESULTS}

\section{Health structure}

The Southeastern and Southern Regions in Brazil are composed of seven states, concentrating more than $55 \%$ of the whole Brazilian population, in spite of comprising only $17 \%$ of the national territory ${ }^{(9,11)}$. Data obtained 
from above mentioned websites demonstrated that, aside from high population, these States also have a high number of healthcare services (more than $65 \%$ of Brazilian healthcare services), mainly under private administration, representing a complex healthcare structure, with high concentration of services. A wide range of healthcare services/population ratio was verified, showing that these services are unevenly available in the region (Table 1 ).

Table 1 - Characteristics and aspects of healthcare structure in the Brazilian States of the Southeast and Southern Regions - São Paulo, 2013

\begin{tabular}{|c|c|c|c|c|c|}
\hline State & Population (N) & $\begin{array}{l}\text { Healthcare } \\
\text { Services* }(N)\end{array}$ & Hospitals (N) & $\begin{array}{l}\text { Ratio Private Service / } \\
\text { Public Service }\end{array}$ & $\begin{array}{l}\text { Ratio Healthcare Service / } \\
\text { Population X 10,000 inhab. }\end{array}$ \\
\hline Espírito Santo & $3,514,952$ & 5,241 & 113 & 3.2 & 14.91 \\
\hline Minas Gerais & $19,597,330$ & 30,716 & 650 & 2.5 & 15.67 \\
\hline Rio de Janeiro & $15,989,929$ & 15,34 & 560 & 3.8 & 9.59 \\
\hline São Paulo & $41,262,199$ & 58,033 & 890 & 6.0 & 14.06 \\
\hline Paraná & $10,444,526$ & 19,423 & 499 & 4.1 & 18.60 \\
\hline Rio Grande do Sul & $10,693,929$ & 19,004 & 337 & 3.8 & 17.77 \\
\hline Santa Catarina & $6,248,436$ & 12,488 & 228 & 3.5 & 19.99 \\
\hline
\end{tabular}

${ }^{*}$ All of the healthcare services were registered in the Brazilian Registry of Health institutes (CNES).

Source: Ministry of Health of Brazil (www.cnes.datasus.gov.br) and Brazilian Institute of Geography and Statistics (IBGE, www.ibge.gov.br), 2012.

\section{Operational structure of surveillance services}

Three out of seven States had an independent organizational unity for HAl surveillance; the others dealt with the HAl subject simultaneously with other activities, accumulating tasks from other sectors.

The human resources placed on the HAl service ranged from one to six professionals, and the professionals carrying out these functions were pharmacists, physicians, dentists, veterinarians, nurses and administrative technicians. In every State there was at least one nurse on the team.

In regard to material resources, three SHD have a exclusive physical area for dealing with the HAl surveillance subject and four of them share the same physical area with other sectors; multimedia projection equipment and televisions for educational purposes are available to all. Personnel for administrative support were found in only three SHD. The number of computers varied from one to six, in accordance with the team. Only three SHD have free internet access; four states have restricted access. The existence of an official regiment to rule the service was mentioned in four of the SHD.

\section{HAI Surveillance Systems}

\section{Surveillance methods}

$\mathrm{HAl}$ incidence surveys were found in all States, however only two use prevalence surveys. Healthcare services that report data to SHD are mainly acute care hospitals, being either general or specialized. Aside from these services, four SHD mentioned data reported from other types of healthcare settings: mixed care units (primary and specialized care), day-hospitals, emergency centres, obstetric centres and public health laboratories (information on microbiological data).

All SHD use Central Venous Catheter-associated Bloodstream Infections (CVC-BSI) as a HAl indicator, notification of which is recommended by the Brazilian National Agency for Sanitary Surveillance (ANVISA).

Five SHD also monitor Catheter-associated Urinary Tract Infection (UTI), Ventilator-associated Pneumonia (VAP), and Surgical Site Infection (SSI). Other additional indicators have being used in a few SHD, such as: microorganism isolated in CVC-BSI (in two states); Multidrugresistant Bacteria Infection and Colonization (one state); Antimicrobial Consumption (one state); Infection associated to Natural Birth and Cesarean Section (one state), and specific indicators for Long-Term Healthcare Settings such as Pneumonia, Scabies, and Gastroenteritis (one state).

\section{Information systems}

Periodicity for sending data varied from weekly to monthly or semi-annual. Three SHD have specific legislation for mandatory periodic report.

In regard to data transmission, one of the SHD referred to the use of only printed forms; three used electronic media (two of them by means of spreadsheets sent by email and one by direct transmission in real time - online). In the other remaining SHD, transmission occurred by either printed forms or electronic media (spreadsheets).

Feedback of results was usually found to be given to participating hospitals, except in two of the SHD. In three of them this feedback happens during meetings or annual scientific events, and other results are given by means of printed reports or electronic media.

Analysis of detailed operational characteristics of the information systems allowed us to understand the flow of information in each SHD and to classify them according to the categories previously defined. These flows were classified as circle in four SHD, as chain in two SHD, and as wheel in one of them. 


\section{Quality of data}

Periodical maintenance or review of the system was reported as being performed in five SHD. The frequency of this procedure may vary among SHD, being monthly (one), annual (one) or irregular (three). In most of situations (six) the personnel in SHD are in charge of it; one SHD has outsourced this activity.

Only two SHD perform quarterly data audits; however, managers reported that these are more likely to be an eventual evaluation and discussion with participating hospitals with data outliers, than to be a systematic process.

Planning and execution of educational activities focused on the surveillance system are established in all of the SHD. These activities may occur by attendance in presence courses or web conferences, with variable periodicity depending on the SHD (semi-annual, annual or undetermined).

\section{DISCUSSION}

This study intends to offer a more judicious point of view in regard to government construction of HAI surveillance systems for standardization of practices, bringing lights to the relevance of this theme with regards to public health. The knowledge of the characteristics of HAl government surveillance systems may allow guidance in public policies and favors initiatives aiming at homogenization or even unification of some systems.

The State usually plays a strategic role in the quality of HAI surveillance. It is mainly responsible for structuring the minimum resources needed to guide the surveillance planning, leading to key actions for prevention and control of $\mathrm{HAl}^{(2,12-13)}$. The surveillance system should be planned in such a way that allows connection with other governmental structures to promote joint actions with efficacy and opportunity.

The herein studied Brazilian regions represent large areas of territory, with intense cultural, structural and economical diversity, concentrating a high contingent of population and healthcare settings ${ }^{(9)}$. Taking into account these features, those Brazilian States are, to some extent, comparable to many other countries in the world in terms of complexity. Furthermore, the Brazilian healthcare system grants autonomy to the States through decentralization of actions to determine their processes of disease control. Accordingly, this level of government plays a role of formulator of action and policies, which include $\mathrm{HAl}$ prevention and control. Aside from its intrinsic prevention role, the State works as a central articulation component in a network, composed of public and private healthcare settings, municipalities, and also at federal level.
It is relevant to start discussions on what could be the minimal structure which should be considered for HAl government surveillance, taking into account the dimension of each State apparatus. This structure must be sufficient to guarantee the integration with other areas of knowledge aiming to deal with the multiple aetiology characteristics of $\mathrm{HAI}$.

Hence the complex nature of technical and political issues determining responsibility for structuring services and teams to deal with HAl prevention and control. Nevertheless, and in face of the great diversity found, the question raised is which would be the minimal required physical and human resources for a surveillance team to be structured at government level? Aside from that, which would be the required and recommended professional categories and competencies for composing these teams? We observed that all States included nurses in their team of HAl prevention and control. Historically, the nursing practice was highly interspersed by infection prevention and control activities since the works of Florence Nightingale ${ }^{(14)}$. Surveillance of diseases have been since then inherently linked to nursing activities; notwithstanding to this, the role of nurses in the States could not be distinguished in our study which suggest needs for further studies.

Consensus standards have been published recommending the core components for an effective HAl program at national level; despite this, specific studies on the minimal structure for this were not found and these questions remain unanswered ${ }^{(15-16)}$.

Our study revealed differences in characteristics in developing HAl surveillance systems, bringing up the diversity in the status of the infection prevention at the States. As for similarities these systems had in common the tendency to mirror great world models, primarily in the North-American model National Nosocomial Infections Surveillance (NNIS), currently incorporated in the National Healthcare Safety Network (NHSN), precursor of this process and the main reference model for world ${ }^{(3-4)}$.

HAl surveillance throughout the world, with few exceptions, is still strongly focused on incidence data, where result indicators are especially monitored in certain infectious sites ${ }^{(12,17-18)}$. This reality was also found in the Brazilian context. Pioneer systems such as European systems - German model Krankenhaus Infektions Surveillance System (KISS) - advanced in the monitoring of $\mathrm{HAl}$, by means of including indicators other than infection outcomes, such as process and structure indicators $^{(6-7,19-21)}$. Other systems such as the Dutch Preventie van Ziekenhuisinfecties door Surveillance (PREZIES) also have incorporated annual prevalence studies without detriment to periodic incidence studies ${ }^{(6-7,20-22)}$. As an advantage, prevalence studies may add a complementary point of view, provided they look at all infection sites in all wards and not exclusively in intensive care. 
Overall the HAI government surveillance systems have both common as well divergent characteristics. The identification of these aspects may be the first step to build an action plan to unify them, respecting economic and cultural diversity and seeking to integrate information ${ }^{(2,12-13)}$.

To allow this potential unification among different surveillance systems the actions developed must be articulated, including data gathering, ways and means to transfer data, analysis and even feedback to participants, bringing efficiency and effectiveness to the process ${ }^{(12-13,23)}$. Agile systems supported by transmission mechanisms, such as software or even spreadsheets, tend to be more efficient than paper, due to speed and reliability throughout the surveillance process ${ }^{(13,23)}$. Nevertheless, this aspect alone does not guarantee quality of the final product; minimal standardization of characteristics needs to be adopted in accordance with monitoring intentions.

Moreover, a continuous education of the system feeders is essential to meet the basic standards of data acquisition. This action associated with the implementation of other tools for supporting data quality, such as auditing, are required for good reliability in the process ${ }^{(13,18)}$. This auditing must not be seen as isolated actions, aiming only

\section{REFERENCES}

1. Lin MY, Hota B, Khan YM, Woeltje KF, Borlawsky TB, Doherty JA, et al. Quality of traditional surveillance for public reporting of nosocomial bloodstream infection rates. JAMA. 2010;304(18):2035-2041.

2. Thacker SB, Qualters JR, Lee LM. Public health surveillance in the United States: evolution and challenges. MMWR Surveill Summ. 2012;61 Suppl:3-9.

3. Dudeck MA, Horan TC, Peterson KD, Allen-Bridson K, Morrell G, Pollock DA, et al. National Healthcare Safety Network (NHSN) report, data summary for 2010, device-associated module. Am J Infect Control. 2011;39(5):798-816.

4. Dudeck MA, Horan TC, Peterson KD, Allen-Bridson K, Morrell G, Pollock DA, et al. National Healthcare Safety Network (NHSN) report, data summary for 2009, device-associated module. Am J Infect Control. 2011;39(5):349-67.

5. Mertens R, Van Den Berg JM, Fabry J, Jepsen OB. HELICS: a European project to standardise the surveillance of hospital acquired infection, 1994-1995. Euro Surveill. 1996;1(4):28-30.

6. Coello R, Gastmeier P, de Boer AS. Surveillance of hospitalacquired infection in England, Germany, and The Netherlands: will international comparison of rates be possible? Infect Control Hosp Epidemiol. 2001;22(6):393-7.

7. Gastmeier P. European perspective on surveillance. J Hosp Infect. 2007;65 Suppl 2:159-64. to verify data consistency. Its implementation must be wide and educationally planned in cycles of continuous improvement ${ }^{(24)}$. However, in the Brazilian regions evaluated, data auditing actions are incipient. This may possibly be due to the difficulties of incorporating auditing activities into a system that is still going through the structuring process.

Governmental agencies should work together with the various healthcare facilities, integrating effective networks of specialized investigation and ongoing monitoring. Both the reliability of the data and the effectiveness of the prevention process are dependent upon the quality of this network ${ }^{(2,21)}$.

\section{CONCLUSION}

Brazil is undergoing a relatively recent process of construction of HAl surveillance systems at a governmental level. The present study can be a reference for other countries also developing their surveillance systems or even regions that aspire to establish unified systems. It also presents itself as a reflection model for a government process to construct HAI surveillance systems.

8. Hansen S, Sohr D, Geffers C, Astagneau P, Blacky A, Koller W, et al. Concordance between European and US case definitions of healthcare-associated infections. Antimicrob Resist Infect Control. 2012;1(1):28.

9. Paim J, Travassos C, Almeida C, Bahia L, Macinko J. The Brazilian health system: history, advances, and challenges. Lancet. 2011;377(9779):1778-97.

10. Buono AF, Bowditch JL. Elementos de comportamento organizacional. São Paulo: Pioneira; 1992.

11. Brasil. Ministério do Planejamento Orçamento e Gestão; Instituto Brasileiro de Geografia e Estatística, Coordenação de Trabalho e Rendimento. Pesquisa Nacional por amostras de Domicílio: Síntese de Indicadores, 2008. Rio de Janeiro: IBGE; 2009.

12. St Louis M. Global health surveillance. MMWR Surveill Summ. 2012;61 Suppl:15-9.

13. Rolka H, Walker DW, English R, Katzoff MJ, Scogin G, Neuhaus E; Centers for Disease Control and Prevention. Analytical challenges for emerging public health surveillance. MMWR Surveill Summ. 2012;61 Suppl:25-9.

14. Gill CJ, Gill GC. Nightingale in Scutari: her legacy reexamined. Clin Infect Dis. 2005;40(12):1799-805. 
15. Seto WH, Otaíza F, Pessoa-Silva C. Core components for infection prevention and control programs: a world health organization network report. Infect Control Hosp Epidemiol. 2010;31(9):948-50.

16. Moro ML, Jans B, Cookson B, Fabry J. The burden of healthcare-associated infections in European long-term care facilities. Infect Control Hosp Epidemiol. 2010;31 Suppl 1:559-62.

17. Drehobl PA, Roush SW, Stover BH, Koo D. Public health surveillance workforce of the future. MMWR Surveill Summ. 2012;61 Suppl:25-9.

18. Bryce EA, Scharf S, Walker M, Walsh A. The infection control audit: the standardized audit as a tool for change. Am J Infect Control. 2007;35(4):271-83.

19. Gastmeier P, Geffers C, Sohr D, Dettenkofer M, Daschner F, Rüden $\mathrm{H}$. Five years working with the German nosocomial infection surveillance system (Krankenhaus Infektions Surveillance System). Am J Infect Control. 2003;31(5):316-21.
20. Mannien J, Van den Hof S, Brandt C, Behnke M, Wille JC, Gastmeier P. Comparison of the national surgical site infection surveillance data between The Netherlands and Germany: PREZIES versus KISS. J Hosp Infect. 2007;66(3):224-31.

21. Nogueira-Junior C, Mello DS, Padoveze MC, Boszczowski I, Levin AS, Lacerda RA. Characterization of epidemiological surveillance systems for healthcare-associated infections (HAl) in the world and challenges for Brazil. Cad Saúde Pública. 2014;30(1):11-20.

22. Geubbels EL, Mintjes-de Groot AJ, Van den Berg JM, de Boer AS. An operating surveillance system of surgical-site infections in The Netherlands: results of the PREZIES national surveillance network. Infect Control Hosp Epidemiol. 2000;21(5):311-8.

23. Savel TG, Foldy S. The role of public health informatics in enhancing public health surveillance. MMWR Surveill Summ. 2012;61 Suppl:20-4.

24. Hay A. Audit in infection control. J Hosp Infect. 2006;62(3):270-7.

\section{Acknowledgements}

We wish to thank all of the individuals who were essential for this study to be implemented: government managers of HAl control and prevention in the Brazilian States of the Southeast and Southern regions. The Funding the State of São Paulo Research Foundation (FAPESP) financed and subsidized this study under process number 2012/02700-7, with dispatch issued on May 09, 2012.

Correspondence addressed to: Maria Clara Padoveze

Department of Collective Health, School of Nursing, University of São Paulo

Av. Dr. Enéas de Carvalho Aguiar, 419

CEP - 05403-000 - São Paulo, SP, Brazil

Email: padoveze@usp.br 